\title{
TOURISM CLUSTERS AND INNOVATION SECURITY: DIALECTICS IN THE WESTERN BORDER REGIONS OF RUSSIA
}

\author{
Vasilisa Valeryevna GOROCHNAYA \\ South Federal University, Academy of Psychology and Educational Sciences, Nagibina av., 14, 344006, \\ Rostov-on-Don, Russian Federation; Immanuel Kant Baltic Federal University, Institute \\ of Environmental Management, Urban Development and Spatial Planning, Zoologicheskaya \\ Str., 2, 236016, Kaliningrad, Russian Federation, e-mail: tunduk@hotmail.com
}

\begin{abstract}
Andrey Sergeevich MIKHAYLOV*
Immanuel Kant Baltic Federal University, Institute of Regional Studies, Innovation Geography Laboratory, Gaidara Str., 6, 236029, Kaliningrad, Russian Federation; Saint Petersburg Electrotechnical University

"LETI”, 197022, Saint-Petersburg, Russian Federation, e-mail: mikhailov.andrey@yahoo.com
\end{abstract}

\section{Anna Alekseevna MIKHAYLOVA}

Immanuel Kant Baltic Federal University, Institute of Regional Studies, Centre for Baltic Studies, Gaidara Str., 6, 236029, Kaliningrad, Russian Federation, e-mail: tikhonova.1989@mail.ru

\section{Angelina Petrovna PLOTNIKOVA}

Immanuel Kant Baltic Federal University, Institute of Regional Studies, Innovation Geography Laboratory, Gaidara Str., 6, 236029, Kaliningrad, Russian Federation, e-mail: APPlotnikova1@kantiana.ru

Citation: Gorochnaya V. V., Mikhaylov A. S., Mikhaylova A. A., \& Plotnikova A. P. (2020). TOURISM CLUSTERS AND INNOVATION SECURITY: DIALECTICS IN THE WESTERN BORDER REGIONS OF RUSSIA. GeoJournal of Tourism and Geosites, 28(1), 127-139. https://doi.org/10.30892/gtg.28110-457

\begin{abstract}
The article provides an assessment of tourism sector impact on regional innovation growth. The research focuses on the border regions of Western Russia experiencing the highest pressure on innovation security under the current situation of losing the established cross-border collaboration ties. The scope of the study covers Bryansk, Kaliningrad, Leningrad, Murmansk, Pskov, and Smolensk regions, Krasnodar Krai, the Republic of Karelia, the city of Saint-Petersburg as nucleus of metropolitan agglomeration. The regions are analysed for their tourism development dynamics, capturing tendencies of growth and strategic development priorities. Both interconnection and independence between tourism and innovation dynamics are identified, resulting in a typology. The best practices pointed out within the selected case studies are assessed as to be transmitted to other regions.
\end{abstract}

Key words: tourism cluster, innovation growth, western Russia, border region

\footnotetext{
${ }^{*}$ Corresponding author
} 


\section{INTRODUCTION}

In many regions around the globe, tourism is one of the major economy sectors featuring high entrepreneurial activity (Klepers \& Rozite, 2009). The high density of business entities, their active involvement in interfirm interactions and cooperation contribute to the process of collective learning, the establishment of a creative environment. The tourism sector is increasingly seen as an important element of economic and innovative development (Aarstad et al., 2015; García-Villaverde et al., 2017; Klepers \& Rozite, 2009; Medina-Muñoz et al., 2013; Martínez-Pérez \& Beauchesne, 2018). As noted by Weidenfeld et al. (2010), tourism plays a significant role in the context of innovative development by supporting knowledge transfer and innovation diffusion. This aspect has been widely discussed in a number of studies, mainly of a qualitative, descriptive nature in the field of hospitality (in Spain by Claver-Cortés et al., 2006; Qatar Mehrez, 2019; the Balearic Islands - Jacob et al., 2003; Martínez-Ros \& Orfila-Sintes, 2009; the USA - Siguaw et al., 2000; Taiwan - Yang, 2007; South Korea - Kim \& Shim, 2018). Hallin and Marnburg (2008) provide an extensive review of early empirical research on these matters. Quantitative studies of the innovative development of tourism are quite rare (Hjalager, 2010; López-Fernández et al., 2011; Martínez-Pérez \& Beauchesne, 2018).

In the last decade, studies have focused on a set of various internal and external factors influencing the innovative activities of tourism sector organisations, including the role of entrepreneurship, the demand for technology, the presence of territorial clusters (Hjalager, 2010) and their competitiveness (Estevão \& Ferreira, 2012; Jin et al., 2012; Jackson \& Murphy, 2006; Jackson, 2006; Hong, 2009), the importance of social capital (Inkpen \& Tsang, 2005; Staber, 2007; Nahapiet \& Ghoshal, 1998).

Tourism companies are traditionally characterized by high dynamism and show ramified intersectoral connectivity, often initiating clustering processes in the region (García-Villaverde et al., 2017; Gomezelj, 2016; Hjalager, 2010). Clustering as a manifestation of "geographically bounded concentration of interdependent businesses with active channels for business transactions, dialogue, and communications, and that collectively shares common opportunities and threats" (Rosenfeld, 1997, p. 4) and "resulting in efficient collaborative synergy" (Kim \& Shim, 2018, p. 2417), plays an important role in providing sustainable competitive advantage. By contributing to "...a variety of flows, within firms, between firms, between producers and consumers, and between private sector and public sector organisations...” (Hudson, 2005, p. 76), the tourism sector makes a significant contribution to the formation of a territorial community through socialization, absorption and learning of implicit knowledge through observation and involvement. A number of scholars believe that tourism agglomerations are crucial for the development and diffusion of innovation (Camisón et al., 2017; Rodríguez et al., 2014; Weidenfeld \& Hall, 2014). Just as industrial enterprises are interdependent with companies in the value chain, tourism clusters are highly dependent on the quality and effectiveness of the companies in their environment outside the framework of a specific market offering. At the same time, the most effective knowledge exchange is carried out with similar companies competing in a single market segment, but located in other regions and countries (Weidenfeld et al., 2010).

According to the OECD report (2006), it is the tourism industry that is most actively involved in the exchange of knowledge and the introduction of innovative solutions, being less protected from imitation and copying (Hall \& Williams, 2008). Due to the possibility of quick replication of innovations, companies generally develop inexpensive products from scratch, but introduce improved innovations (Poon, 1993) in the process of continuous learning. The most common channels for learning and knowledge absorption in tourism are observations - "learning by observing" (Nonaka \& 
Takeuchi, 1995), as well as "staff mobility" and "intercompany exchange" through coordinated visits to destinations, tourism associations and exhibitions, to a lesser extent trade, technology, infrastructure and regulatory systems (Weidenfeld et al., 2010).

The efficiency of tourism clusters as drivers of innovative activity is due to the fact that they help reduce transaction costs of agents, facilitate access to specialized services, investments and other resources in a systematic manner (Funck, 2012). This is especially prominent because, unlike industrial production, tourism products are a collaboration of various enterprises, predominantly small and medium-sized enterprises (SMEe), which experience the need for external capital, research and development, human resources and information more acute than large companies do (Iordache et al., 2010; Michael, 2003; Novelli et al., 2006; Thomas et al., 2011).

Innovation development of regions is one of the key directions of regional policy in Russia. To maintain global competitiveness of production and world standards of live quality, Russia stimulates innovation activities and makes them to be the issue of high priority. The most attention is focused on mechanisms of federal and regional support to the innovative industries, such as machinery, high-tech, chemistry, biotechnology and pharmaceutics, etc. However, the potential of other sectors is underestimated, as they are not directly associated with innovation growth. This research is based on the hypothesis that tourism sector has the capacity to foster innovation growth at the regional level in the modern Russia, especially via the self-organizing mechanisms of clustering. The study is purposed to identify both direct and indirect effects of innovation growth caused by (or synchronized with) the development of tourism.

We address the question of whether the investments into tourism sector of regional economy can be the means to enforce regional innovation security, by analysing the factors and best practices of advanced regions. Another issue raised is the role of tourism in innovation security (innovation resilience). We focus on the border and coastal regions of western Russia as territories under the highest influence of the geo-economic turbulence in the 'Russia-West' system since 2014. The mechanisms of overcoming certain negative trends do work already in the general international trade interaction and in some cases - within productive cooperation of enterprises, but they do not efficiently work within the sphere of investments (which are vitally important to cover the risks of innovative activities), as well as within mutual science and R\&D projects. That is why innovation security, being sensitive to external shocks and changes, is one of the most urgent issues within their general economic security. As most of western border regions of Russia used to be integrated into the European economic space and perform the innovation flows from the West, they try to fulfil the loss of previous partners and contacts by intra-regional integration of business initiatives, using the centres of science and education as the platforms for such interaction (Gorochnaya et al., 2019; Mikhaylova, 2018; 2019).

\section{RESEARCH BACKGROUND}

The current geo-economic situation and the need for import substitution since 2014 have been causing the waves of clustering (with the interval of approximately 2 years), spreading across the Western Russia from the leading centres - St. Petersburg, Rostov and Kaliningrad region, as they are the areas of early clustering in Russia. But the clustering in Kaliningrad region initially had the impetus from the European neighbourhood, so at the present time there is lack in 'critical mass' of enterprises and investments to form real clusters in the most of sectors. In other Western border regions the waves of clustering include more and more basic industries of regional specialization (starting with the most competitive ones), including tourism (Gorochnaya, 2019). 
The average level of innovatization in the Western border regions reflected in the statistical data on the aggregate volume of innovative goods and services has remained lower than national average. Since 2014, despite the general Russian decline, the stable intensified growth dynamics in registered in this category of regions (Figure 1).

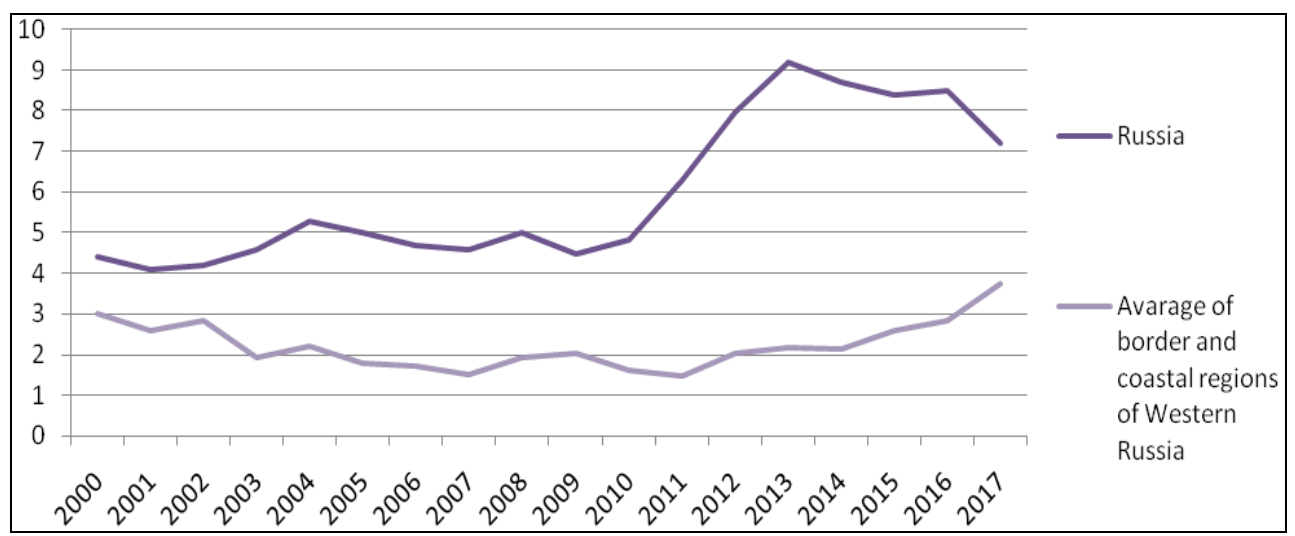

Figure 1. Dynamics of the share of innovation product in the total volume of goods and services (Source: based on Rosstat, 2018)

This trend reflects the internal self-organizing impetus to substitute innovation production from abroad and to use the appeared niches in the internal market. On the one hand, in the most part of cases such growth is beginning in the hi-tech machinery, as it is more likely to be innovative-oriented, and the clustering involves enterprises, R\&D and scientific-educational institutions that already have comparatively strong relations and the experience of common projects. However, on the other hand, in some regions the process of clustering began from the initial experience of tourism sector, and then spread to other industries (Gorochnaya, 2019). In such cases, tourism becomes the core of initial clustering that gives the indirect effect of further selforganizing enforcement of innovative production, for being the local competitive advantage and specialisation, and the integrator of the regional organizational capacity.

In addition, tourism services can become the direct consumer of local innovation product or even the generator of innovations. The practice of Russian regions includes the best practice of the Republic of Tatarstan. The modernization and development of tourism in the Republic during the last two decades actively involved application of new technologies (incl. improved infrastructure, enhanced museum and sightseeing experience with digital technologies) that ultimately gave the new impetus of economic and innovation growth. Similar development strategy can be applied to the Western border regions experiencing 'structural holes' due to distortion of networks. The potential of tourism sector to lead, integrate and form the additional demand for innovation industries is to be estimated in terms of regional clustering dynamics (Osipova at al., 2017) and the specifics of coastal areas (Druzhinin et al., 2017a; 2017b; Mikhaylov, 2019).

\section{MATERIALS AND METHODS}

As the first step of the study, we identified the target regions of tourism development among the entire Western border and coastal regions of Russia, accordingly to both present developed and high potential of touristic business and regional strategies, including the priorities of developing touristic sector. Based on an inventory of previously identified set of emerged and potential clusters in the Western border regions 
(Gorochnaya, 2019), we explored those cases, when clustering process in a region started (or is strategically planned to start) from the tourism sector.

Additional attention drawn to the regions, where, despite the absence of officially registered tourism clusters, tourism sector is significant and has a potential for clustering due to the competitive advantages and long-term development history. The direct and indirect interaction with other industries is included into account. The initial materials for such cluster and proto-cluster observation is taken from a wide range of official webresources of public bodies (containing the strategic documents and directives on tourism cluster development), enterprises, officially institutionalized clusters and regional Centres of cluster development, informative periodicals and press on discussing the tourism clusters' perspectives in the regions. Both formal and informal regional clustering of tourism organizations and enterprises of associated industries are viewed to be the marker of actual or potential growth of the sector via the mechanisms of selforganization. It helped to identify the number of particular regions, where the clustering in the sphere of tourism is significant or have the background to develop.

The second step of the study provided the complex statistic evaluation of tourism development of the chosen regions. The evaluation is carried out in static and dynamic extent. The static evaluation of tourism sector of the regions (the data by Rosstat on the 2018) includes two aspects: the service volume index and the organizational density index. The primary indicators are: the number of travel agencies, the number of travel packages sold, the number of outbound tourists, the number of collective accommodation facilities, the number of persons placed in collective accommodation facilities, the number of sanatoriums and resorts, the number of persons placed in health resort and wellness organizations.

All the primary indicators of tourism development are weighted on the number of population of a region (per 1000 of population). The number of travel agencies, the number of collective accommodation facilities and the number of organizations of sanatorium profile are weighted on the entire number of organizations within a region (per 1000 organizations). The general index of tourism development calculated as the average geometrical of all the weighted primary indicators (equation 1).

$$
I_{G}=\sqrt[N]{\frac{1000 i_{1}}{M} \cdot \ldots \cdot \frac{1000 i_{N}}{M}},
$$

$I_{G}-$ general index: $i_{1}, \ldots, i_{N}-$ primary indicators, $N$ - number of indicators, $M-$ number of regional population (for the service volume index) of the number of population (for the organizational density index).

The dynamic evaluation of both service and organizational environment is carried out by calculating the average geometrical growth rates per year for a number of periods: for 13 years (2005-17), 8 years (2010-17), 4 years (2014-17), 2 years (2016-17) to identify the periods of acceleration and also to compare the development before and after 2014 as the year of radical external changes.

For every region and for every period the general growth rate is calculated as the average geometrical of all the weighted primary indicators' growth rates, multiplied on 100 , final result to be measured in \% (equation 2).

$$
R_{G}=\sqrt{\frac{i_{L 1} \cdot M_{0} \cdot 100}{i_{01} \cdot M_{L} \cdot L} \cdot \ldots \cdot \frac{i_{L N} \cdot M_{0} \cdot 100}{i_{0 N} \cdot M_{L} \cdot L}},
$$


$R_{G}$ - overall growth rate, $i_{o}$ - primary indicator value in the beginning year, $i_{L}-$ primary indicator value in the last year of the period, $L$ - the duration of the period (measured in the number of years), $M_{O}$ - the number of population (or the number of organizations) in the region in the first year of the period, $M_{L}$ - the number of population (or the number of organizations) in the region in the last year of the period, $N$ - number primary of indicators. The calculated general static indexes and the average growth rates provide comparative data of the regions studied, reflected visually by the means of cartography and resulted in the typology of regions by to their touristic development.

The third step of the study is the comparative assessment of innovation security of the chosen regions by the three major indicators: the share of innovative goods, works and services in the total volume of goods shipped, works performed, services; the ratio of the cost of technological innovation and R\&D costs; the ratio of the volume of shipped innovative products and the cost of technological innovation. These indicators are extensively elaborated by the Baltic school of economic geographers (Problems of Economic Security, 2019). As all of them are relative measures, they do not need to be weighted on the number of population or organizations.

The official statistical data of the Russian Federal State Statistics Service is used (Rosstat, 2018). The comparison between tourism development and the rates of innovation security used for the final typology, as various types of the regions need different directions and measures of regional policy and have various background and recreational potential to induct innovation growth.

\section{RESULTS DISCUSSIONS}

After the analysis of the empirical materials, tourism clusters or their prototypes are identified in Krasnodar Krai, Saint-Petersburg (incl. the Leningrad region), Kaliningrad, Pskov, Smolensk, Bryansk, Murmansk regions and the Republic of Karelia (Table 1).

Table 1. Genesis of clusters in the border regions of Western Russia, $\mathrm{O}$ - overall number of clusters emerged, including: $\mathrm{T}$ - the number of tourism clusters emerged

\begin{tabular}{|c|c|c|c|c|c|c|c|c|c|c|}
\hline \multirow{2}{*}{ Region } & \multicolumn{2}{|c|}{ Before 2014} & \multicolumn{2}{|c|}{ 2014-15 } & \multicolumn{2}{|c|}{ 2016-17 } & \multicolumn{2}{|c|}{ 2018-19 } & \multicolumn{2}{|c|}{$\begin{array}{c}\text { Potential and } \\
\text { planned }\end{array}$} \\
\hline & $\mathbf{O}$ & $\mathbf{T}$ & $\mathbf{O}$ & $\mathbf{T}$ & $\mathbf{O}$ & $\mathbf{T}$ & $\mathbf{O}$ & $\mathbf{T}$ & $\mathbf{0}$ & $\mathbf{T}$ \\
\hline Krasnodar region & - & - & 1 & 1 & 1 & - & - & - & 3 & - \\
\hline Rostov region & 7 & - & 7 & - & 2 & - & 1 & - & 4 & 1 \\
\hline Voronezh region & - & - & 9 & - & - & - & 2 & - & 1 & - \\
\hline Belgorod region & - & - & 1 & - & 1 & - & - & - & 4 & - \\
\hline Kursk region & - & - & - & - & 1 & - & - & - & 4 & - \\
\hline Bryansk region & - & - & 1 & 1 & 1 & 1 & 1 & - & 3 & - \\
\hline Smolensk region & - & - & - & - & 4 & 1 & - & - & - & - \\
\hline Pskov region & - & - & - & - & 2 & 1 & - & - & - & - \\
\hline Kaliningrad region & 7 & 1 & - & - & - & - & - & - & 1 & - \\
\hline Leningrad region & - & - & - & - & - & - & 4 & - & 1 & 1 \\
\hline Saint-Petersburg & 4 & - & 3 & - & 5 & - & 1 & 1 & - & - \\
\hline Republic of Karelia & - & - & - & - & - & - & 2 & 1 & 2 & - \\
\hline Murmansk region & - & - & 1 & 1 & - & - & 2 & - & - & - \\
\hline Arkhangelsk region & 1 & - & 1 & - & - & - & - & - & - & - \\
\hline
\end{tabular}

This analysis defined the following types of regions:

1. The regions of early clustering, where tourism clusters emerged along with other industries as the result of competitive advantages of the region and touristic sphere being one of regional specialization industries (e.g. Kaliningrad region). 
2. The regions, where tourism sector in 2014-15 became the first economy sector to initiate clustering self-organization, and then this impetus transmitted to other industries, including innovative ones (e.g. Krasnodar, Bryansk and Murmansk regions).

3. The regions, where tourism clusters emerged along with other ones as the attempt to integrate local potential during 2016-19 or are planned for the nearest future (e.g. Smolensk and Pskov regions, St. Petersburg and Leningrad region, Republic of Karelia). In such cases, the impetus comes from other successful and experienced sectors of regional economy to tourist business.

4. The region, where tourism clusters are in the process of official institutionalization, but is more of a formal attempt to enforce the developing sector than the real clustering, despite there are some perspectives (e.g. Rostov region). The region is well developed in terms of clusters, but the tourism potential is modest and touristic infrastructure is still developing.

5. Regions without significant attempts for self-organization of tourism clusters (e.g. Voronezh, Belgorod, Kursk and Arkhangelsk regions). Some of them have tourist potential, but the enterprises are not interested in clustering, and the regional administration is focused on other competitive sectors.

It is notable that tourism (along with IT) is the sphere where sub-clustering is more likely than in other sectors of clustering. It happens due to the nature of tourism services that tend to divide into sub-clusters on the particular territories or focused on the particular kinds of tourism (event, medical-therapeutic, visiting historical and cultural heritage, marine-coastal, etc.). On the one hand, firms specialize at particular profile and territory within the region, so they join the sub-cluster.

On the other hand, the touristic flows come from one area to another, touristic operators make new routes that connect various objects spread in the territory of a region, and organizations of various profile work on the complex product for tourists. Such subclustering trend increases the organizational density of a region, leads to diversification and makes the business more flexible and adaptive to the market changes. That is why tourism became the first sector of clustering for some regions, where the other industries are not presented by the enough integrative organizational mass. In other regions it became the sphere which had no internal impetus for clustering, but in the changeable external situation it performed the same trend with other regional economy. In both cases, it demonstrates the enforcement of interaction with other regional industries, directly or indirectly interconnected with tourism services, and also for some regions tourism clustering became the way to develop interactions with other (neighbouring) regions (Table 2). As seen from calculating and mapping the general integrated index if tourism performance (Figure 1), the self-organizing trends after 2014 really caused the growth of the sector during the last 2-3 years, especially in Leningrad and Kaliningrad regions (more than 20\% average growth per year). This brought them to the leading positions of Russian tourism regions. Murmansk region (18\%), Krasnodar, Bryansk and Pskov regions (10-12\%), Smolensk region (8\%), St. Petersburg (6\%) improved their infrastructure and attractiveness. The least developed northern regions also showed growth, especially high in 2016-2017 in Murmansk region (18\%) and modest in Karelia Republic. It did not change their poor positions radically, but probably their tourism sector has the perspectives. It is also noticeable that during the 2017 the growth rates were lower in the most of regions (exceptions are Krasnodar region and Karelia Republic), and in S. Petersburg the growth rate is even negative. It probably means the enforcement of competition with other regions.

Similar patterns identified for the organizational development of the tourist sector in the regions studied (Figure 3). Data suggests that organizational density has increased, with the growth starting 2-3 years earlier than the general growth of tourism services. 
Table 2. Tourism sub-clustering, interactions with other clusters and cross-regional perspectives in the Western border and coastal regions of Russia

\begin{tabular}{|c|c|c|c|}
\hline Region & $\begin{array}{c}\text { Touristic sub- } \\
\text { clustering }\end{array}$ & Names of (sub)clusters & $\begin{array}{l}\text { Interaction with other } \\
\text { clusters and regions }\end{array}$ \\
\hline $\begin{array}{c}\text { Krasnodar } \\
\text { region }\end{array}$ & 3 & $\begin{array}{l}\text { Cluster "Abrau-Utrish", the cluster } \\
\text { of marine tourism of the Big Sochi } \\
\text { and the cluster of mountain tourism } \\
\text { of the Big Sochi }\end{array}$ & $\begin{array}{l}\text { Potential interaction with } \\
\text { forming agro-business and } \\
\text { industrial cluster }\end{array}$ \\
\hline $\begin{array}{c}\text { Bryansk } \\
\text { region }\end{array}$ & - & Cluster "Crystal city" & - \\
\hline $\begin{array}{c}\text { Smolensk } \\
\text { region }\end{array}$ & - & "Tourist cluster Smolensk" & - \\
\hline $\begin{array}{l}\text { Pskov } \\
\text { region }\end{array}$ & - & “Tourist cluster Pskovian” & $\begin{array}{l}\text { Potentially cross-border with } \\
\text { Novgorod and Leningrad regions }\end{array}$ \\
\hline $\begin{array}{c}\text { Kaliningrad } \\
\text { region }\end{array}$ & 7 & $\begin{array}{l}\text { "Raushen", "Kranz", "Palmniken", } \\
\text { "Neukuhren", "Pillau", "European } \\
\text { Baikal" (using the recreational } \\
\text { resources of the lake Vishtynetskoye } \\
\text { in Nesterovsky district of the region) } \\
\text { and "Königsberg" }\end{array}$ & $\begin{array}{l}\text { Potentially cross-border with EU; } \\
\text { interconnected with the Amber } \\
\text { cluster of Kaliningrad region, } \\
\text { interconnected with previously } \\
\text { existed furniture cluster }\end{array}$ \\
\hline $\begin{array}{l}\text { Saint- } \\
\text { Petersburg } \\
\text { and } \\
\text { Leningrad } \\
\text { region }\end{array}$ & \multicolumn{2}{|c|}{$\begin{array}{l}\text { In the process of official institutionalizing, the } \\
\text { present versions of the names are: "Tourist cluster } \\
\text { of St.-Petersburg" and "Old Ladoga" ("Bolshaya } \\
\text { Ladoga") }\end{array}$} & $\begin{array}{l}\text { Potentially cross-border with } \\
\text { Novgorod and Pskov regions; } \\
\text { interconnected with the group of } \\
\text { clusters of city infrastructure and } \\
\text { technologies (cluster of innovation } \\
\text { development in energy and } \\
\text { industry, cluster of water supply } \\
\text { and sanitation, cluster of clean } \\
\text { technologies for the urban } \\
\text { environment of information } \\
\text { technologies) of St. Petersburg }\end{array}$ \\
\hline $\begin{array}{c}\text { Republic } \\
\text { of Karelia }\end{array}$ & 2 & $\begin{array}{l}\text { "Legends of Karelia" and "The } \\
\text { Karelian White Sea" }\end{array}$ & $\begin{array}{l}\text { Interconnected with the forming } \\
\text { cluster of creative activities }\end{array}$ \\
\hline $\begin{array}{c}\text { Murmansk } \\
\text { region }\end{array}$ & 11 & $\begin{array}{l}\text { "Hibiny" (Apatity and Kirovsk), } \\
\text { "Belomore" (Kandalaksha and Tersky } \\
\text { districts), "Sub-cluster of Lovozersky } \\
\text { district", "Sub-cluster of the Pechenga } \\
\text { district", "Murmansk", Proto-cluster } \\
\text { "Teriberka" (in the formation stage); } \\
\text { "Polyarnye Zori city"; "Monchegorsk } \\
\text { city"; "Olenegorsk city"; “The Kovdor } \\
\text { district" and "Kola district" }\end{array}$ & $\begin{array}{l}\text { Interconnected with the } \\
\text { forming cluster of creative } \\
\text { activities }\end{array}$ \\
\hline
\end{tabular}

Data sources: Minenkova, 2017; Komsomlskaya Pravda Bryansk, URL: https://www.bryansk.kp.ru/ daily/26544.7/3560447; Smolensk region Centre for cluster development, URL: https://ckr67.ru/klastery; Rosstat 2018 on Pskov region, URL: http://gkk.pskov.ru/sites/default/files/analiticheskaya zapiska turizm.pdf; Invest in Kaliningrad region, URL: https://investinkaliningrad.ru; Invest in The Republic of Karelia, URL: http://kareliainvest.ru/republic-forinvestors/projects/turizm; Kaliningrad region development corporation, URL: https://www.kgd-rdc.ru; Murmansk region Centre for cluster development, URL: http://murmancluster.ru; St. Petersburg Centre for cluster development, URL: https://spbcluster.ru/tourism cluster; Russian news agency TASS, URL: https://tass.ru/obschestvo/4793675; Karelia tourist centre, URL: http://www.ticrk.ru; Tourism cluster in St. Petersburg, URL: https://tourclusterspb.ru; Tourism cluster in Smolensk region, URL: https://turcluster67.ru; Tourist information centre of Leningrad Region. URL: https://www.lentravel.ru/novosti/gubernator-leningradskojoblasti-utverdil-pasport-prioritetnogo-proekta-sozdanie-turistsko-rekreacionnogo-klastera-v-staroj-ladoge.html

It means that it is the organizational multiplication and clustering effect to bring the further development of the sector and to increase the productive performance. It is especially seen by the examples of the Republic of Karelia and Smolensk region, but not 
the Leningrad region, where clustering trend is only beginning to develop at the present time. However, the comparison with the rates and dynamics of innovation security shows the further differentiations of the regions on the interconnection or disconnection between tourism, clustering and innovations (Figure 4).

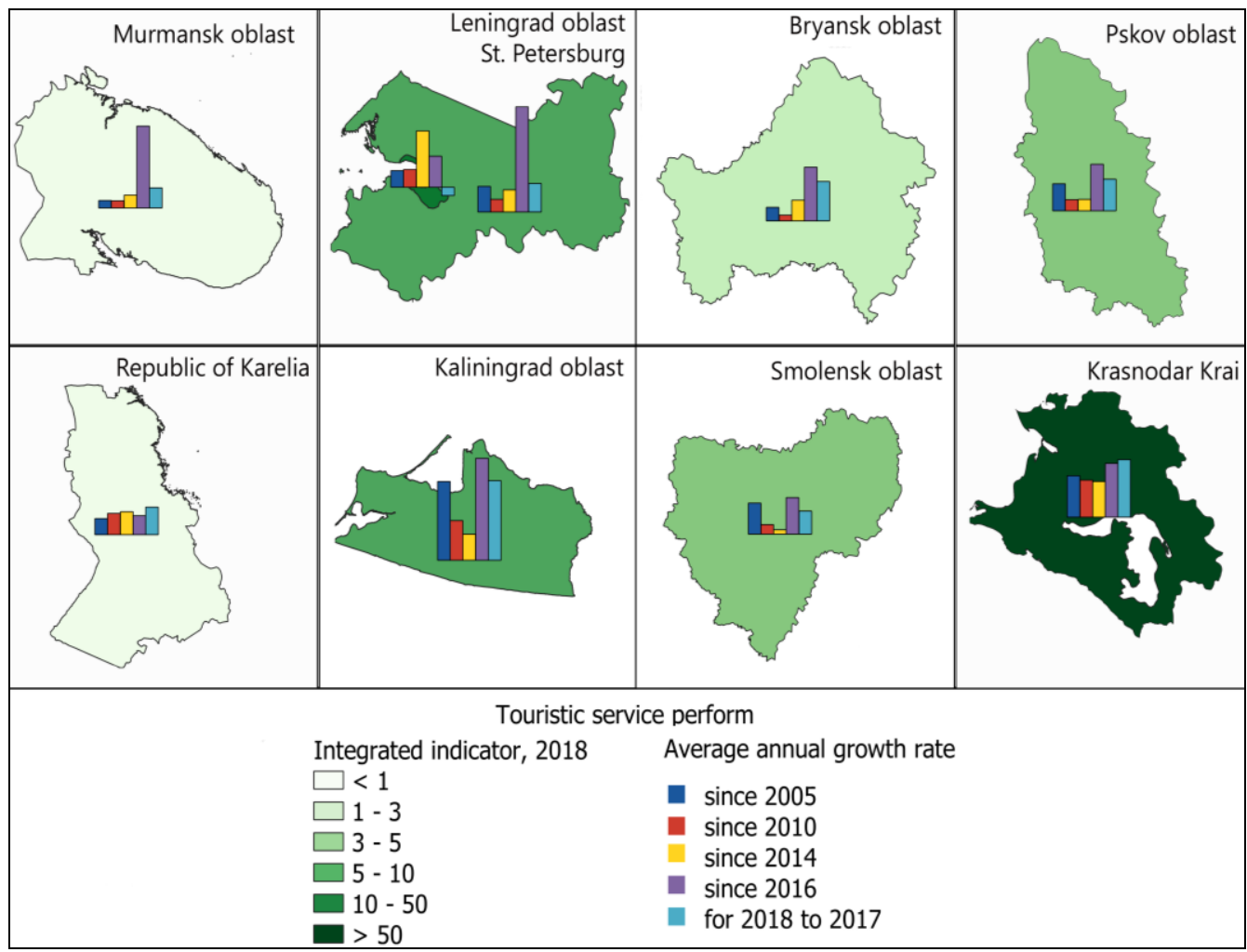

Figure 2. Tourism service volume index and growth rates (Source: based on Rosstat, 2018)

The regions are further divided into five groups:

1. The leader region in both tourism performance and innovation security Krasnodar region. Being initially the most attractive southern region, it has grown over the past 5 years with the help of federal state investments into the project of Summer Olympic Games 2018. The improved infrastructure uses the new technologies, and the multiplication effect takes place. From the tourism industry the clustering trend comes to other economy sectors, which had no impetus previously (in comparison with the neighbouring Rostov region with the similar agro-industrial profile, where effective clustering began about 2 decades ago). Therefore, it caused the superior innovation growth of the entire southwestern territories.

2. Regions with comparatively high touristic performance at the background of medium or even poor innovation security: Kaliningrad region, St. Petersburg, Pskov region. This is caused by the real challenges to their innovation security after the geoeconomic shift of 2014, combined with the relative independence of tourist sector from innovation growth (the local recreational resources have the 'critical mass' for internal growth). It is interesting to compare such fact with the active clustering of innovative production industries in this group of regions (including IT clusters in Kaliningrad region, the wide range of hi-tech clusters in St. Petersburg and one forming in Pskov region). 
3. Region with high level of innovation security at the background of poor tourism development - Bryansk region, where the innovation growth is forming in the industries of machinery; and the tourism is to become the new additional sector of development, according to the current regional policy that stimulates tourism clustering.

4. Regions with medium but equivalent rates in both innovations and tourism: Leningrad and Smolensk regions.

5. Northern regions with modest performance in both innovations and tourism: the Republic of Karelia and Murmansk region.

Despite the differentiation, all the categories of regions perform growth in both directions that has significantly increased in rates since 2014 and especially since 2016.

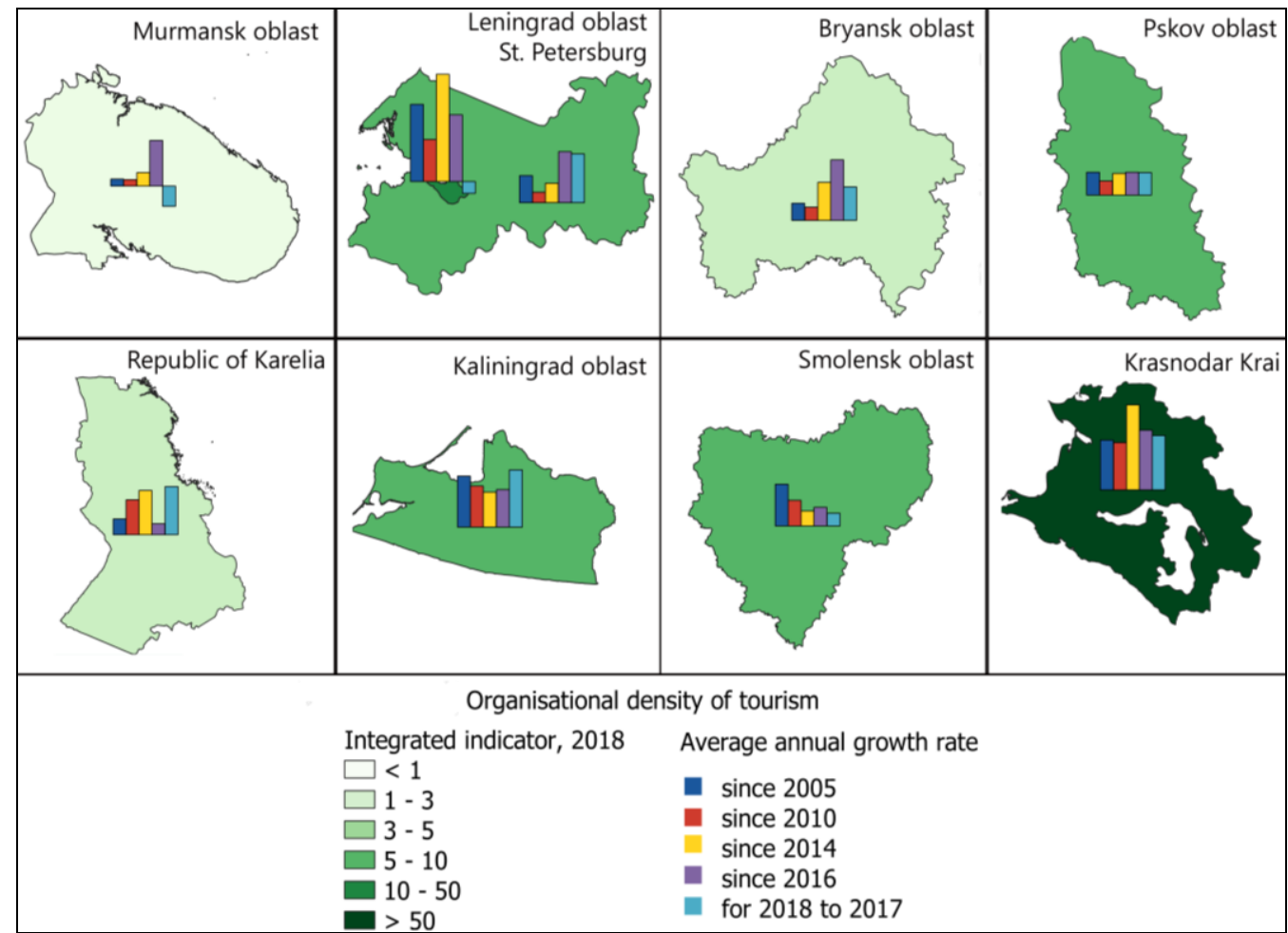

Figure 3. Tourist organizational density index and growth rates (Source: based on Rosstat, 2018)

\section{CONCLUSION}

The research results have proven that the initial shift of external conditions in 2014 has influenced the development of both innovation and tourism spheres in the Western border and coastal regions of Russia, causing the waves of clustering self-organization. However, the real interconnection between innovation security and tourism clustering is identified only in the Krasnodar region, which leads in innovation security and becomes increasingly attractive and prestigious for tourists. Nevertheless, this successful example of both private and state investments in innovations can be embodied in other regions.

The complex innovation strategy in tourism is needed in the modern Russia. The identified growth proves that cluster integrative mechanisms multiply the investments. The regions with superior tourism development need both financial and coordination support in widespread dissemination of innovations. The industrially and innovatively developed areas need the organizational initiatives and coordination between the innovators and local 
touristic centres, including a stronger integration with academic and higher education institutions. The transfer of best practice on to regions with medium and poor developed tourism should be based on the place-adaptive policy principle, thus, taking into account the specifics of local cross-industry interdependencies. The study has shown that the general growth of tourism during the past decade has changed significantly.

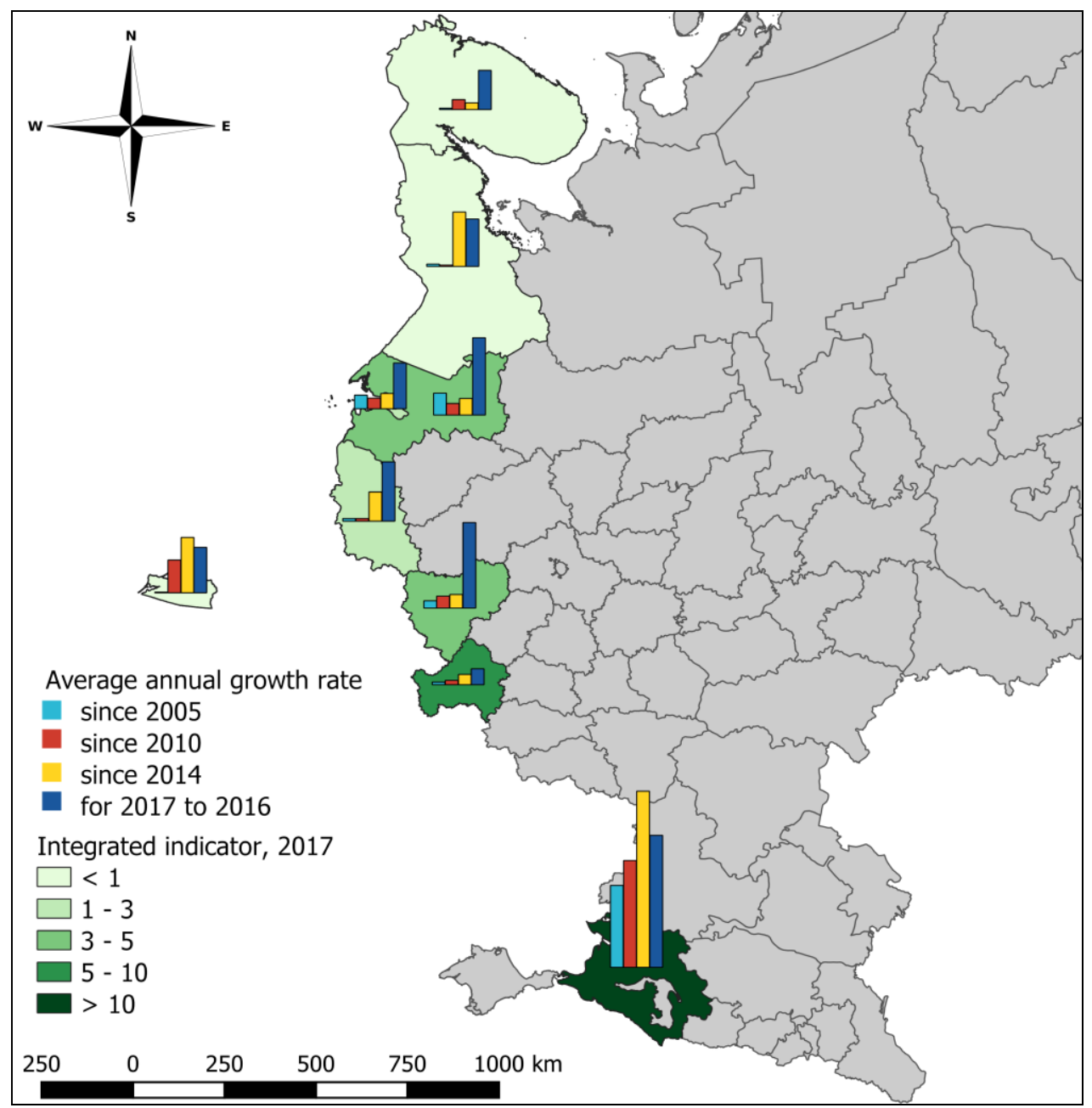

Figure 4. General integrated rate of innovation security of the Western border and coastal regions (Source: based on Rosstat, 2018)

The geopolitical shift of 2014 caused the need to find and activate all the possible resources for the further development and compensation of the lost possibilities and the negative economic trends. The tourism specialization is re-enforced not only in Krasnodar and Kaliningrad regions traditionally featuring tourism as part of major specialization, but also in northern regions with the strategy to generate new growth nodes. The growth of organizational density in 2014-15 and the following growth of performance caused change in the vectors of touristic flows shifting from the traditional centres to the developing periphery. Therefore, the growing cross-regional competition is the new challenge for the tourism industry, boosting cluster initiatives even in St. 
Petersburg and the adjacent Leningrad region. We believe that the growing competition at the cross-regional market will push both clustering trend and the growth in using and developing innovations across industries. However, the multiplication and the final positive result will be much more in the case of the special attention and support from both regional administration and the federal centre. As the self-organization takes place, the indirect regulation is needed to create the conditions for the market rentable projects at the intersection of traditional tourism attractions and innovations.

\section{Acknowledgments}

The study was funded by RFBR according to the research project No. 19-010-01083 "Problems of Innovation Security and Mechanisms of Cluster Economic Development of the Border Regions of the European Part of Russia”.

\section{REFERENCES}

Aarstad, J., Ness, H., \& Haugland, S.A. (2015). Innovation, uncertainty, and inter-firm shortcut ties in a tourism destination context. Tourism Management, vol.48, no.1, p. 354-361.

Camisón, C., Forés, B., \& Boronat-Navarro, M. (2017). Cluster and firm-specific antecedents of organizational innovation. Current Issues in Tourism, vol.20, p. 617-646.

Claver-Cortés, E., Molina-Azorín, J.F., \& Pereira-Moliner, J. (2006). Strategic groups in the hospitality industry: Intergroup and intragroup performance differences in Alicante, Spain. Tourism Management, vol.27, no.6, p. 1101-1116.

Decelle, X. (2006). A dynamic conceptual approach to innovation in tourism. In OECD (Ed.), Innovation and tourism policy, p. 85-105, OECD Publishing.

Druzhinin, A. G., Fedorov, G. M., Mikhaylov, A. S., Gontar, N. V., Gorochnya, V. V., Lachininskii, S. S., \& Volkhin, D. A. (2017a). Typology of Coastal Zones in the European Part of Russia: Modern Particularities within the Trend of Cross-border Clustering. Journal of Applied Economic Sciences, vol.12, no.5(51), p. 1451-1460.

Druzhinin, A. G., Gorochnya, V. V., Gontar, N. V., Mikhaylov, A. S., Fedorov, G. M., Lachininskii, S. S., \& Dets, I. A. (2017). Economic Clusters in Coastal Areas of the European Part of Russia: Typological Invariance and Specifics of Localization. Espacios, vol.38, no.59, p. 5 .

Estevão, C., \& Ferreira, J.J. (2012). Tourism cluster positioning and performance evaluation: the case of Portugal. Tourism Economics, vol.18, no.4, p. 711-730.

Fedorov G.M. ed. (2019). Problems of Economic Security of the Western Border Regions of Russia. Monograph. 267 p., I. Kant Baltic Federal University Press, Kaliningrad.

Funck, C. (2012). The innovative potential of inbound tourism: in Japan for destination development - a case study of Hida Takayama. Contemporary Japan, vol.24 no.2, p.121-147.

García-Villaverde, P.M., Elche, D., Martínez-Pérez, Á., \& Ruiz-Hortega, M.J. (2017). Determinants of radical innovation in clustered firms of the hospitality and tourism industry. International Journal of Hospitality Management, vol.61, p. 45-58.

Gomezelj, D. O. (2016). A systematic review of research on innovation in hospitality and tourism. International Journal of Contemporary Hospitality Management, vol.28 no.3, p. 516-558.

Gorochnaya, V. V. (2019). Clustering and Innovation Security in the Regions of Western Russia: Inventory and Main Development Trends. Regional economy and management: electronic scientific journal, no.3 (59). Art. \#5911. Date issued: 2019-07-25. Available at: https://eee-region.ru/article/5911/

Gorochnaya, V. V., Mikhaylov, A., S., \& Kirik, V. A. (2019). Education Clusters in Fostering Innovation Security: Experience of Rostov and Kaliningrad Regions in Western Russia. 2nd International Conference on Education Science and Social Development (ESSD 2019). Advances in Social Science, Education and Humanities Research, vol.298, p. 523-527.

Hall, C. M., \& Williams, A. M. (2008). Tourism and innovation. London: Routledge.

Hallin, C.A., \& Marnburg, E. (2008). Knowledge management in the hospitality industry: A review of empirical research. Tourism Management, vol.29, no.2, p. 366-381.

Hjalager, A.-M.(2010). A review of innovation research in tourism. Tourism Management, vol.31, no.1, p. 1-12.

Hong, W.C. (2009). Global competitiveness measurement for the tourism sector. Current Issues in Tourism, vol.12, no.2, p. 105-132.

Hudson, R. (2005). Economic geographies, circuits, flows and spaces. London: Sage.

Inkpen, A., \& Tsang, E. (2005). Social capital, networks, and knowledge transfer. Academy of Management Review, vol.30, p.146-165.

Iordache, C., Ciochinã, I., \& Asandei, M. (2010). Clusters-tourism activity increase competitiveness support. Theoretical and Applied Economics, vol.17, no.5, p. 99-112. 
Jackson, J. (2006). Developing regional tourism in China: the potential for activating business clusters in a socialist market economy. Tourism Management, vol.27, no.4, p. 695-706.

Jackson, J., \& Murphy, P. (2006). Clusters in regional tourism an Australian case. Annals of Tourism Research, vol.33, no.4, p. 1018-1035.

Jacob, M., Tintoré, J., Aguiló, E., Bravo, A., \& Mulet, J. (2003). Innovation in the tourism sector: Results from a pilot study in the Balearic Islands. Tourism Economics, vol.9, no.3, p. 279-295.

Jin, X., Weber, K., \& Bauer, T. (2012). Impact of clusters on exhibition destination attractiveness: evidence from mainland China. Tourism Management, vol. 33, no.6, p. 1429-1439.

Kim, N., \& Shim, C. (2018). Social capital, knowledge sharing and innovation of small- and medium-sized enterprises in a tourism cluster. International Journal of Contemporary Hospitality Management, vol.30, no.6, p. 2417-2437.

Klepers, A., \& Rozite, M. (2009). Tourism as a tool of sustainable regional development and the importance of clusters in Latvia: The example of Sigulda and Ventspils. WIT Transactions on Ecology and the Environment, vol.120, p. 823-832.

López-Fernández, M.C., Serrano-Bedia, A.M., \& Gómez-López, R. (2011). Factors encouraging innovation in Spanish hospitality firms. Cornell Hospitality Quarterly, vol.52, no.2, p. 144-152.

Martínez-Pérez, Á., \& Beauchesne, M.-M. (2018). Overcoming the Dark Side of Closed Networks in Cultural Tourism Clusters: The Importance of Diverse Networks. Cornell Hospitality Quarterly, vol.59, no.3, p. 239-256.

Martínez-Ros, E., \& Orfila-Sintes, F. (2009). Innovation activity in the hotel industry. Technovation, vol.29, no.9, p. 632-641.

Medina-Muñoz, D.R., Medina-Muñoz, R.D., \& Zúñiga-Collazos, A. (2013). Tourism and innovation in China and Spain: A review of innovation research on tourism. Tourism Economic, vol.19, no.2, p. 319-337.

Mehrez, A. (2019). Investigating the effectiveness of practicing knowledge management in the hospitality industry: The case of Qatar. International Journal of Knowledge Management Studies, vol.10, no.2, p. 101-117.

Michael, E. (2003). Tourismmicro-clusters. Tourism Economics, vol.9, no.2, p. 133-145.

Mikhaylov, A.S. (2019). Coastal agglomerations and the transformation of national innovation spaces. Baltic Region, vol. 11, no.1, p. 29-42.

Mikhaylova, A.A. (2018). The dimension of innovation in the economic security of Russian Regions. European Journal of Geography, vol. 9, no.4, p. 88-104.

Mikhaylova, A.A. (2019). In pursuit of an innovation development trajectory of the Kaliningrad region. Baltic Region, vol. 11, no.3, p. 92-106.

Minenkova, V. V. (2017). Tourism clusters in the Krasnodar region. Tourism and regional development, p. 169174. Smolensk.

Nahapiet, J., \& Ghoshal, S. (1998). Social capital, intellectual capital, and the organizational advantage. Academy of Management Review, vol.23, p. 242-266.

Nonaka, I., \& Takeuchi, H. (1995). The knowledge creating company: How the Japanese companies create the dynamics of innovation. New York: Oxford University Press.

Novelli, M., Schmitz, B. \& Spencer, T. (2006). Networks, clusters and innovation in tourism: a UK experience. Tourism Management, vol.27, no.6, p. 1141-1152.

Osipova, N. I., Ivanova, N. V., \& Aksyonova, L. A. (2017). Innovation Directions of Development of Regional Touristic Clusters. Vestnik RMAT, no.4, p. 110-114.

Poon, A. (1993). Tourism, technology and competitive strategies. Wallingford, UK: CAB International.

Rodríguez, I., Williams, A. M., \& Hall, C. M. (2014). Tourism innovation policy: Implementation and outcomes. Annals of Tourism Research, vol.49, p.76-93.

Rosenfeld, S., A. (1997). Bringing business clusters into the mainstream of economic development. European Planning Studies, vol.5, no.1, p. 3-23.

Rosstat (2018). http://www.gks.ru, accessed 04.10.2019-13.12.2019.

Siguaw, J.A., Enz, C.A., \& Namasivayam, K. (2000). Adoption of information technology in U.S. hotels: Strategically driven objectives. Journal of Travel Research, vol.39, no.2, p. 192-201.

Staber, U. (2007). Contextualizing research on social capital in regional clusters. International Journal of Urban and Regional Research, vol.31, p. 505-521.

Thomas, R., Shaw, G. \& Page, S.J. (2011). Understanding small firms in tourism: a perspective on research trends and challenges. Tourism Management, vol.32, no.5, p. 963-976.

Weidenfeld, A., \& Hall, C. M. (2014). Tourism in the development of regional and sectoral innovation systems. In A. Lew, C. M. Hall, \& A. Williams (Eds.), The Wiley Blackwell companion to tourism, p. 578-588, Oxford, UK: Wiley- Blackwell.

Weidenfeld, A., Williams, A.M., \& Butler, R.W. (2010). Knowledge transfer and innovation among attractions. Annals of Tourism Research, vol.37, no.3, p. 604-626.

Yang, J.-T. (2007). Knowledge sharing: Investigating appropriate leadership roles and collaborative culture. Tourism Management, vol.28, no.2, p. 530-543.

Submitted:

26.11.2019
Revised:

06.02.2020
Accepted and published online 12.02.2020 